\title{
Bone turnover in early rheumatoid arthritis. 1. Biochemical and kinetic indexes
}

\author{
P N SAMBROOK, ${ }^{1 *}$ B M ANSELL, ${ }^{1}$ S FOSTER, ${ }^{1}$ J M GUMPEL ${ }^{1}$ R HESP, ${ }^{1}$ \\ J REEVE, ${ }^{1}$ AND J M ZANELLI ${ }^{2}$
}

From the ${ }^{1}$ MRC Clinical Research Centre and Northwick Park Hospital, Watford Road, Harrow, Middlesex; and the ${ }^{2}$ National Institute for Biological Standards and Control, London

SUMMARY Biochemical, hormonal, and kinetic indexes of bone turnover were measured in 17 ambulant female patients with rheumatoid arthritis (RA) of recent onset (mean disease duration 14.2 months) and 19 controls. Mean serum osteocalcin concentration and ${ }^{85} \mathrm{Sr}$ accretion rates were reduced and mean urinary hydroxyproline-creatinine ratios were increased in RA, but these differences were not significant compared with control values. Mean total body potassium (TBK), an index of skeletal muscle mass, was significantly reduced in RA, and the ratio of observed to predicted TBK correlated with indexes of bone formation. No abnormality of skeletal metabolism could be shown in early RA, but reduced rates of bone formation associated with diminished muscle mass may influence the development of osteopenia later in the disease.

Key words: calcium kinetics, osteocalcin, total body potassium.

Osteoporosis is a well recognised complication of RA and is generally considered to be of two types. A juxta-articular form of osteoporosis is one of the earliest radiological features of $\mathrm{RA}^{1}$ and this appears to be mediated by local disease mechanisms. ${ }^{2-4}$ More generalised involvement of the axial and peripheral skeleton may also occur, and it has been suggested that this is a manifestation of a generalised disturbance of skeletal metabolism. $^{5}$

Assessment of skeletal metabolism in RA is complicated by effects not only of the disease process but also, as the disease progresses, of disuse due to progressive loss of mobility, chronic therapy with drugs which may affect bone metabolism, ${ }^{6-8}$ and sometimes poor nutrition and concomitant corticosteroid therapy.

In the present study we have measured biochemical, hormonal, and kinetic indexes of bone turnover in ambulant patients with RA of recent onset and in a group of age and sex matched controls. By choosing such patients we have attempted to reduce the complicating effects of factors such

Accepted for publication 12 March 1985.

Correspondence to Dr J Reeve, Clinical Research Centre, Watford Road, Harrow, Middlesex HA1 3UJ.

*Present address: Garvan Institute, St Vincent's Hospital, Sydney, NSW 2010, Australia. as loss of mobility and corticosteroid therapy. Since among RA patients who have not been treated with corticosteroids postmenopausal women are the group most at risk of developing osteoporosis, ${ }^{910}$ we selected for study predominantly postmenopausal women who had recently developed RA.

\section{Patients and methods}

S U B J E C T S

Female patients attending two general rheumatology outpatient clinics who had developed seropositive classical or definite $\mathrm{RA}^{11}$ in the preceding three years and who were approaching the menopause or were postmenopausal were asked to participate; patients receiving oral corticosteroids were excluded.

Control subjects were volunteers in good health and not taking drugs known to produce osteoporosis; two were taking non-steroidal antiinflammatory drugs for minor degenerative joint disease.

Plasma calcium, phosphate, and creatinine were normal in all subjects. Details of patients and controls are shown in Table 1. Informed consent was obtained from each subject and the study received Ethical Committee approval. 
Table 1 Clinical details of patients and controls

\begin{tabular}{lll}
\hline Clinical details & $\begin{array}{l}\text { Rheumatoid arthritis } \\
\text { patients }(n=17)\end{array}$ & $\begin{array}{l}\text { Controls } \\
(n=19)\end{array}$ \\
\hline $\begin{array}{l}\text { Age (years): } \\
\quad \text { Mean }\end{array}$ & $55 \cdot 4$ & \\
$\quad$ Range & $37-66$ & $56 \cdot 5$ \\
No. postmenopausal & 12 & $41-69$ \\
$\begin{array}{l}\text { No. years postmenopausal: } \\
\quad \text { Mean }\end{array}$ & $11 \cdot 1$ & 15 \\
$\quad$ Range & $2-22$ & $9 \cdot 4$ \\
$\begin{array}{l}\text { Disease duration (months): } \\
\quad \text { Mean }\end{array}$ & $15 \cdot 0$ & $1-22$ \\
$\quad$ Range & $5-31$ & - \\
Physical activity index & & - \\
$\quad$ Mean \pm SD) & $30 \cdot 1 \pm 2 \cdot 6$ & $31 \cdot 5 \pm 2 \cdot 6$ \\
\hline
\end{tabular}

A subjective assessment of physical activity was made in both groups by the Framingham activity index. ${ }^{12}$ Disease activity was assessed at the start of the study in patients by the following: Ritchie articular index ${ }^{13}$; joint count (number of active joints); grip strength (mean of three recordings, dominant hand); erythrocyte sedimentation rate (ESR); C-reactive protein (CRP).

\section{A B O R A T ORY S T U D I ES}

Accretion rates were determined using ${ }^{85} \mathrm{Sr}$ as an intravenous tracer for calcium and a kinetic model employing the technique of impulse analysis. ${ }^{14}$ The ${ }^{85} \mathrm{Sr}$ accretion rate provides an estimate of the mass of calcium taken up by the skeleton in one day which remains there for at least 20 days and is not available for short-term exchange. By use of a whole body counter ${ }^{85} \mathrm{Sr}$ retention was monitored for five months, and the impulse response function of the skeleton for tracer $\mathrm{H}(\mathrm{t})$ was calculated by deconvolution analysis. ${ }^{15}$ The impulse response function describes the fate of a 'cohort' of calcium atoms that enter the skeleton in one day. The values of $\mathrm{H}(\mathrm{t})$ at 20 and 200 days were calculated from the function, and the fraction of accreted tracer lost in the first six months was calculated as $\left(\mathrm{H}_{20}-\mathrm{H}_{200}\right) / \mathrm{H}_{20}$.

Urinary calcium, creatinine, and hydroxyproline concentrations were measured in all subjects two hours after an overnight fast. With these quantities expressed in $\mathrm{mmol} / \mathrm{l}$ a calcium:creatinine ratio greater than 0.45 and a hydroxyproline:creatinine ratio greater than 0.016 were taken to indicate increased net bone resorption. ${ }^{16}$

The total body content of potassium (TBK) was determined in each subject, a whole body counter being used to detect the $1.46 \mathrm{MeV}$ gamma rays associated with the decay of naturally occurring ${ }^{40} \mathrm{~K} .{ }^{17}$ TBK results were also expressed as the ratio of observed to expected TBK (TBK O/E), where predicted TBK was calculated using the empirica formula of Boddy et al. ${ }^{18}$ which describes TBK in normal women in relation to their weight, height: and age.

Fasting venous blood samples were taken at theo start of the kinetic studies and the serum extracted and stored at $-70^{\circ} \mathrm{C}$ until assay. Radioimmuno $\frac{\bar{\rho}}{\bar{D}}$ assays were performed with commercial kits manu再 factured by Immuno Nuclear Corporation Stillwater, Minnesota, USA. Serum parathyroid? hormone (PTH) was measured by a radioimmuno? assay procedure which recognises human para $\overrightarrow{\vec{H}}$ thyroid fragments containing the 44-68 amino aciळ sequence of the hormone. Purified bovine PTH was used for standard and tracer. Each determination was carried out in triplicate. The sensitivity of the assay was $10 \mathrm{pmol} / \mathrm{l}$. Serum calcitonin was deterir mined by a radioimmunoassay procedure which recognises the 17-32 amino acid sequence of humang calcitonin. Pure human synthetic calcitonin was used as antigen for the antiserum, as radioiodinateds tracer, and as standard. Non-equilibrium incubation conditions were used to improve sensitivity. Each? determination was carried out in triplicate. The्ठ sensitivity of the method was $60 \mathrm{pg} / \mathrm{ml}(\mathrm{ng} / \mathrm{l})$. Serum osteocalcin was determined by radioimmunoass $\$ \vec{y} \overrightarrow{0}$ Purified carboxylated bovine osteocalcin was useç for standard and tracer. Each determination carried out in duplicate. The sensitivity of the assays was $0.8 \mathrm{ng} / \mathrm{ml}(\mu \mathrm{g} / \mathrm{l})$.

Unpaired $t$ tests were used to determine signifi cance levels of differences between mean values in the two groups. Radioimmunoassay results tha were non-detectable were treated as censored normal data, and mean values were determined by computer by the maximum likelihood theory. Parametric correlation analyses were performed of the various disease activity measures against indexes. of bone turnover. For this purpose osteocalciri values were corrected for creatinine clearance and body surface area. ${ }^{20}$

\section{Results}

The results of the studies for patients and controls are shown in Table 2 . There was a trend for patient with RA to have lower indexes of bone formations and higher indexes of bone resorption, but thesev differences were not statistically significant.

Observed TBK values and the ratio TBK O/E were significantly reduced in RA patients compare

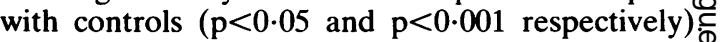
The ratio TBK O/E for both patients and controls combined correlated significantly with accretiono $(\mathrm{r}=0.47, \mathrm{p}<0.01), \mathrm{H}_{20} \quad(\mathrm{r}=0.38, \mathrm{p}<0.05), \quad \mathrm{H}_{20} \overrightarrow{\mathrm{P}}$ $(r=0.42, p<0.05)$, and serum osteocalcin $(r=0.51$ ه 
Table 2 Bone turnover indexes (mean $\pm S D$ )

\begin{tabular}{|c|c|c|}
\hline & Rheumatoid arthritis patients $(n=17)$ & Controls $(n=19)^{*}$ \\
\hline $\begin{array}{l}\text { Indexes of bone formation: } \\
\text { Accretion (mmol Ca/day) } \\
\mathrm{H}_{20} \quad \text { (mmol Ca/day) } \\
\mathrm{H}_{200} \text { (mmol Ca/day) } \\
\text { Serum osteocalcin }(\mathrm{ng} / \mathrm{ml})^{\dagger}\end{array}$ & $\begin{array}{l}5 \cdot 0 \pm 2 \cdot 1 \\
4 \cdot 0 \pm 1 \cdot 7 \\
2 \cdot 7 \pm 1 \cdot 2 \\
3 \cdot 2 \pm 1 \cdot 6\end{array}$ & $\begin{array}{l}5 \cdot 7 \pm 2 \cdot 1 \\
4 \cdot 4 \pm 1 \cdot 5 \\
3 \cdot 2 \pm 1 \cdot 5 \\
3 \cdot 8 \pm 1 \cdot 6\end{array}$ \\
\hline $\begin{array}{l}\text { Indexes of bone resorption: } \\
\text { Urinary calcium:creatinine } \\
\text { Urinary hydroxyproline:creatinine } \\
\left(\mathrm{H}_{20}-\mathrm{H}_{200}\right) / \mathrm{H}_{20}\end{array}$ & $\begin{array}{l}0 \cdot 37 \pm 0 \cdot 22 \\
0 \cdot 021 \pm 0 \cdot 013 \\
0 \cdot 32 \pm 0 \cdot 12\end{array}$ & $\begin{array}{l}0 \cdot 39 \pm 0 \cdot 15 \\
0 \cdot 017 \pm 0 \cdot 007 \\
0 \cdot 29 \pm 0 \cdot 12\end{array}$ \\
\hline $\begin{array}{l}\text { Calciotropic hormones: } \\
\text { Serum PTH (pmol/l) } \\
\text { Serum calcitonin }(\mathrm{pg} / \mathrm{ml})^{\dagger}\end{array}$ & $\begin{array}{l}82 \cdot 3 \pm 35 \cdot 0 \\
60 \cdot 0 \pm 27 \cdot 0\end{array}$ & $\begin{array}{l}68 \cdot 7 \pm 33 \cdot 7 \\
68 \cdot 2 \pm 29 \cdot 0\end{array}$ \\
\hline $\begin{array}{l}\text { Skeletal muscle mass: } \\
\text { Observed TBK (mmol) } \\
\text { TBK O/E }\end{array}$ & $\begin{array}{l}2184 \pm 170 \\
0 \cdot 94 \pm 0 \cdot 11\end{array}$ & $\begin{array}{l}2481 \pm 343 \\
1.06 \pm 0.09\end{array}$ \\
\hline
\end{tabular}

Kinetic studies were performed in only 14 controls and serum PTH, calcitonin, and osteocalcin in only 18 controls.

$+\mathrm{ng} / \mathrm{ml}=\mu \mathrm{g} / \mathrm{l} ; \mathrm{pg} / \mathrm{ml}=\mathrm{ng} / \mathrm{l}$.

$\mathrm{p}<0.01$ ) but not with the fraction of accreted tracer lost in the first six months. Measures of disease activity did not correlate significantly with any index of bone formation, but urinary hydroxyproline: creatinine ratios correlated with several measures of activity including joint count $(r=0.62, p<0 \cdot 01)$, $\operatorname{ESR}(r=0 \cdot 70, p<0 \cdot 01)$, and $\operatorname{CRP}(r=0 \cdot 70, p<0 \cdot 01)$.

\section{Discussion}

Generalised osteoporosis is well known to occur in RA, but uncertainty exists with regard to the mechanism. Duncan et al. ${ }^{5}$ suggested that a primary defect in bone metabolism involving the whole osseous system may occur in RA. By histomorphometric analysis of cortical bone in rib biopsy specimens from seven patients these authors found evidence of increased bone resorption, reduced bone formation, and defective mineralisation in RA. As similar histological changes have been observed in bone after immobilisation, ${ }^{21}$ these findings may reflect a form of disuse osteoporosis.

By choosing ambulant outpatients with disease of recent onset we have attempted to examine the effect of the disease process on the skeleton without the additional influence of factors such as loss of mobility in longstanding disease. By the subjective Framingham index our patient and control groups were well matched in this regard, but TBK results showed a reduction in skeletal muscle mass in RA, so that in practice it was not possible to eliminate this effect completely.

Rates of bone formation assessed by kinetic methods in RA showed a trend towards lower values, but this difference was not statistically significant. All indexes of bone formation correlated with TBK O/E, which is indirectly related to an individual's level of physical activity. This finding is consistent with studies showing that mechanical forces are important determinants of bone formation rates. ${ }^{21} 22$

Previous kinetic studies of bone turnover in RA are few and the findings conflicting. Dymling ${ }^{23}$ measured accretion rates in patients with RA and osteopenia and found a mean reduction in accretion of $16 \%$ but considered these values to be normal when related to the diminished skeletal mass. Heaney et al. found that local accretion rates in areas of bone with active joint disease were increased two- to fivefold, but that whole body accretion values were normal, suggesting that reduced remodelling was taking place in bone uninvolved in the rheumatoid process. Bergmann et al. ${ }^{25}$ similarly found that accretion rates were increased near involved joints, but that whole body accretion rates were also slightly increased. The latter results were interpreted as evidence for increased bone remodelling in juxta-articular bone but did not support the suggestion that bone turnover was altered in the remainder of the skeleton.

Each of these studies used kinetic methods to determine accretion rates that include ion exchange processes not involved in osteoblastic new bone formation. Since these processes may represent more than half the measured accretion rate, ${ }^{26}$ these studies tend to overestimate rates of bone turnover. The method we employed allowed a correction to be made for long-term ion exchange processes by extension of the usual study from three weeks to five 
months. ${ }^{15}$ To calculate the true apposition and resorption rates would have required a simultaneous calcium balance which was not performed, but the quantity $\mathrm{H}_{200}$ is a measure of exchange corrected skeletal uptake.

The other index of bone formation we measured was serum osteocalcin. Osteocalcin is a vitamin $\mathrm{K}$ dependent bone protein containing three $\gamma$ carboxyglutamic acid residues. ${ }^{27}$ Its function in bone is unknown, but serum levels are increased in diseases characterised by increased bone turnover ${ }^{28}$ and correlate well with histomorphometric measures of bone formation. ${ }^{29}$ Two recent studies have found reduced serum osteocalcin levels in RA, ${ }^{30} 31$ but in both studies patients had predominantly longstanding disease. These results together with our findings suggest that any substantial reduction in bone formation in RA is relatively unusual early in the disease and when it occurs may possibly be related to reduced physical activity as the disease progresses.

Increased urinary ratios of calcium and hydroxyproline are thought to indicate increased net bone resorption ${ }^{16}$ and have been reported to be both normal $^{32}$ and increased. ${ }^{33}$ In our patients mean urinary calcium:creatinine and hydroxyproline: creatinine ratios were not significantly higher than values for controls, but several patient values were markedly increased, and urinary hydroxyproline ratios correlated with some measures of disease activity. In one previous study urinary hydroxyproline:creatinine levels were found to be higher in patients with more active disease ${ }^{34}$ but this may not indicate increased bone turnover, since urinary hydroxyproline is also derived from the complement protein $\mathrm{Clq},{ }^{35}$ the turnover of which is also increased in RA.

There are few studies of calciotropic hormones in RA. Abnormalities of mineral metabolism suggestive of parathyroid hormone (PTH) excess have been observed in RA, ${ }^{36}$ but the levels of immunoreactive PTH have been found to be normal in two studies. ${ }^{33}{ }^{37}$ Catabolism of PTH involves cleavage of the intact 84 amino acid molecule in the neighbourhood of residue 34 to generate an amino terminal fragment with biological activity and a larger biologically inert fragment containing the mid-region and carboxyl region. ${ }^{38}$ Assays directed against the mid-region may reflect parathyroid secretory activity more specifically than assays against the carboxyl terminal. ${ }^{39} 40 \mathrm{We}$ were unable to show any disturbance in parathyroid gland activity in RA by a mid-molecule PTH assay.

Kennedy et al. ${ }^{37}$ found no abnormality in plasma calcitonin levels in RA with a relatively insensitive assay (sensitivity $100 \mathrm{pg} / \mathrm{ml}(\mathrm{ng} / \mathrm{l})$ ), whereas Orth et $a l .{ }^{30}$ found a reduction in mean calcitonin levels in males but not females with RA. The measurement? of calcitonin by radioimmunoassay is difficult for $\vec{F}$ several reasons. Calcitonin is normally present in $\frac{9}{7}$ serum in very low concentrations and declines with을 age. ${ }^{41}$ Circulating immunoreactive calcitonin is $\frac{\bar{c}}{\bar{s}}$ heterogeneous, and detection varies with different? assays. ${ }^{42}$ The assay we used was more sensitive than that used by Kennedy et al. ${ }^{37}$ but hormone re-ळ mained undetected in many samples and it was not $\overrightarrow{0}$ possible to establish whether subnormal concentrations occur in RA.

No substantial disturbance in skeletal metabolism could be shown in patients with RA of recent onset.⿳亠丷厂 The finding of a small reduction in indexes of bone formation in these patients and the correlationic observed between these indexes and skeletal musclery mass suggests that further studies may clarify the $\mathrm{N}$ role of immobilisation in the pathogenesis of the ? generalised osteoporosis frequently observed in non-steroid treated patients with long-established $\mathbb{\Phi}$ disease.

This work was supported by the Australian Arthritis and Rheuma-足 tism Foundation and the Arthritis and Rheumatism Council of $\vec{C}$ Great Britain. Radioimmunoassy kits were supplied undero $\overrightarrow{0}$ research grant from RIA (UK), Tyne and Wear, UK.

\section{References}

1 Bywaters E G L. The early radiological signs of rheumatoid arthritis. Bull Rheum Dis 1960; 11: 231-4.

2 Robinson D R. Tashjian A M, Levine L. Prostaglandin stimulated bone resorption by rheumatoid synovia. J Clin Invesi 1975; 56: 1181-8.

3 Mizel S B, Dayer J M, Krane S M, Mergenhagen S E. $\overline{\bar{O}}$ Stimulation of rheumatoid synovial cell collagenase and prostaglandin production by purified lymphocyte-activating factor? (interleukin 1). Proc Natl Acad Sci USA 1981; 78: 2475-7.ㅇ.

4 Crisp A J, Roelke M S, Goldring S R, Krane S M. Heparin modulates intracellular cyclic AMP in human trabecular bone cells and adherent rheumatoid synovial cells. Ann Rheum Dis 1984; 43: 628-34.

5 Duncan H, Frost $\mathrm{H}$ M, Villanueva A R, Sigler J W. The osteoporosis of rheumatoid arthritis. Arthritis Rheum 1965; 8:O 943-54.

6 Cooper C W, Doty S B, Talmage R V. Inhibition of boneo collagen synthesis by salicylates. Proc Soc Exp Biol Med $1964 ;$ 117: 881-8.

7 Lerner U. Indomethacin inhibits bone resorption and lysosomal을 enzyme release from bone in organ culture. Scand $J$ Rheumato ${ }_{\mathrm{N}}$ 1980; 9: 149-56.

8 Lindholm T S, Tornkvist $\mathrm{H}$. Inhibitory effect on formation and calcification exerted by the anti-inflammatory drug ibuprofen. N
Scand J Rheumatol 1981; 10: 38-42.

9 Saville P D, Kharmosh O. Osteoporosis of rheumatoid arthritis:O influence of age, sex and corticosteroids. Arthritis Rheum 1967 10: $423-30$.

10 Reid D M, Kennedy N J S, Smith M A, Tothill P, Nuki G. Tota市 body calcium in rheumatoid arthritis: effects of disease activity? and corticosteroid treatment. $\mathrm{Br}$ Med $J$ 1982; 285: 330-2. T

11 Ropes M W, Bennett G A, Cobb S, Jacox R, Jessar A R. Diagnostic criteria for rheumatoid arthritis, 1958 revision. Ann Rheum Dis 1959; 18: 49-53. 
12 Kannel W B, Sorlie P. Some health benefits of physical activity. The Framingham study. Arch Intern Med 1979; 139: 857-61.

13 Ritchie D M, Boyle J A, McInnes J M. Clinical studies with an articular index for the assessment of joint tenderness in patients with rheumatoid arthritis $Q \mathrm{~J}$ Med 1968; 147: 393-406.

14 Reeve J, Wootton R, Hesp R. A new method for calculating the accretion rate of bone calcium and some observations on the suitability of strontium-85 as a tracer for bone calcium. Calcif Tissue Res 1976; 20: 121-35.

15 Reeve J, Hesp R, Wootton R. A new tracer method for the calculation of rates of bone formation and breakdown in osteoporosis and other generalized skeletal disorders. Calcif Tissue Res 1976; 22: 191-206.

16 Nordin B E C. Diagnostic procedures in disorders of calcium metabolism. Clin Endocrinol 1978; 8: 55-67.

17 Smith T, Hesp R, Mackenzie J. Total body potassium calibration for normal and obese subjects in two types of whole body counter. Phys Med Biol 1979; 24: 171-5.

18 Boddy K, King P C, Hume R, Weyers E. The relation of total body potassium to height, weight and age in normal adults. $J$ Clin Pathol 1972; 25: 512-7.

19 Swan A V. Computing maximum likelihood values for parameters of the normal distribution from grouped and censored data. Appl Stat 1969; 18: 65-9.

20 Price $\mathrm{P} \mathrm{A}$, Williamson $\mathrm{M} \mathrm{K}$, Lothringer $\mathrm{J} \mathrm{W}$. Origin of the vitamin $\mathrm{K}$-dependent bone protein found in plasma and its clearance by kidney and bone. J Biol Chem 1981; 256: 12760-6.

21 Minaire P, Meunier P, Edouard C, Bernard J, Courpron P, Bourret J. Quantitative histological data on disuse osteoporosis. Calcif Tissue Res 1974; 17: 57-73.

22 Lanyon L E, Rubin C T. Regulation of bone mass in response to physical activity. In: Dixon A, Russell R G G, Stamp T C B, eds. Osteoporosis: a multidisciplinary problem. London: R Soc Med, 1983: 51-61.

23 Dymling J F. Calcium kinetics in osteopenia and parathyroid disease, Acta Med Scand 1964; 175 (suppl 408): 16-8.

24 Heaney R P, Walch J J, Steffes P, Skillman T G. Periarticular bone remodelling in rheumatoid arthritis. Calcif Tissue Res 1968; 2 (suppl): 33-33B.

25 Bergmann P, Mannicourt D, Martin P, Orleff S, Schoutens A. Regional bone calcium turnover rate in rheumatoid arthritis: comparison with disease activity. Adv Inflamm Res 1982; 3: 303-12.

26 Marshall J H. Measurements and models of skeletal metabolism. In: Comar C L, Bronner F, eds. Mineral metabolism. New York: Academic Press, 1969; 3: 1-122.

27 Hauschka P V, Lian J B, Gallop P M. Direct identification of the calcium binding aminoacid, gamma-carboxyglutamate in mineralized tissue. Proc Natl Acad Sci USA 1975; 72: 3925-9.

28 Price P A, Parthemore J G, Deftos L J, Nishimoto S K. New biochemical marker for bone metabolism. J Clin Invest 1980; 66: 878-83.

29 Brown J P, Delmas P D, Malaval L, Edouard C, Chapuy M C, Meunier P J. Serum bone Gla-protein: a specific marker for bone formation in postmenopausal osteoporosis. Lancet 1984; i: 1091-3.

30 Orth R W, Weisman M H, Catherwood B D, Manolagas̄ S C, Deftos L J. Bone loss in rheumatoid arthritis. Arthritis Rheum 1983; 26 (suppl 4): Abs 100.

31 Riis B J, Als O S, Christiansen C, Catherwood B D, Deftos L J. Bone turnover in rheumatoid arthritis. Calcif Tissue Int 1984; 36 (suppl 2): S4

32 Als O S, Christiansen C, Hellesen C. Prevalence of decreased bone mass in rheumatoid arthritis. Relation to antiinflammatory treatment. Clin Rheumatol 1984; 3: 201-8.

33 Verstraeten A, Guesens P, Dequeker J, Bouillon R. Bone metabolism in rheumatoid arthritis. Calcif Tissue Int 1983; 35 (suppl): Abs 235.

34 Mbuyl J M, Dequeker J, Teblick M, Merlevede M. Relevance of urinary excretion of alcian blue glycosaminoglycan complexes and hydroxyproline to disease activity in rheumatoid arthritis. J Rheumatol 1982; 9: 579-83.

35 Reid $\mathbf{K}$ B $M$, Lane $D$, Porter $R \mathbf{R}$. Isolation and characterisation of $\mathrm{Cl}_{4}$, a subcomponent of the first component of complement, from human and rabbit sera. Biochem J 1972; 130: $749-63$.

36 Kennedy A C, Allam B F, Boyle I T, Nuki G, Rooney P J, Buchanan W W. Abnormalities of mineral metabolism suggestive of parathyroid overactivity in rheumatoid arthritis. Curr Med Res Opin 1975; 3: 345-58.

37 Kennedy A C, Allam B F, Rooney P J, et al. Hypercalcaemia in rheumatoid arthritis, investigation of its causes and implications. Ann Rheum Dis 1979; 38: 401-12.

38 Potts J T, Kronenberg H M, Rosenblatt M. Parathyroid hormone: chemistry. biosynthesis and mode of action. $A d v$ Protein Chem 1982; 35: 323-96.

39 Roos B A, Lindall A W, Aron D C, et al. Detection and characterization of small midregion parathyroid hormone fragment(s) in normal and hyperparathyroid glands and sera by immuno extraction and region-specific radioimmunoassays. $J$ Clin Endocrinol Metab 1981; 53: 709-21.

40 Gallagher J C, Riggs B B L, Jerpak C M, Arnaud C D. The effect of age on serum immunoreactive parathyroid hormone in normal and osteoporotic women. J Lab Clin Med 1980; 95: 373-85.

41 Deftos L J, Roos B A, Bronzert D, Parthemore J C. Immunochemical heterogeneity of calcitonin in plasma. $J$ Clin Endocrinol Metab 1975; 40: 409-12.

42 Snider R H, Silva O L, Moore C F, Becker K I. Immunochemical heterogeneity of calcitonin in man, effect on radioimmunoassay, Clin Chim Acta 1977; 76: 1-14. 